\title{
Vibration transmitted to operator's back by machines with back-pack power unit: a case study on blower and spraying machines
}

\author{
Roberto Deboli, ${ }^{1}$ Angela Calvo, ${ }^{2}$ Venerando Rapisarda, ${ }^{3}$ Christian Preti, ${ }^{1}$ Marco Inserillo' \\ ${ }^{1}$ Italian National Research Council, Institute for Agricultural and Earthmoving Machines (IMAMOT- \\ ER), Torino, Italy ; ${ }^{2}$ DISAFA, University of Turin, Grugliasco (TO), Italy; ${ }^{3}$ Occupational Medicine \\ Department, University of Catania, Catania, Italy
}

\begin{abstract}
To correctly evaluate the vibration transmitted to the operators, it is necessary to consider each body's point interested by the vibratory stimulus produced by machines. All the body's part in contact to the vibration, when a portable device with internal combustion engine is used, are: hands, back and shoulders. Some information for wholebody vibration are available in the ISO 2631-1997 standard, which otherwise refers to a seated operator. ' $C$ ' type standards for the vibration analysis exist for some portable machines with an internal combustion engine which is comprehensive in the machine (chainsaw, brush-cutter, blower). If the engine is not inside the machine, but it is on the operator's back, ' $C$ ' type standards on vibration measurements are quite incomplete. The IMAMOTER institute of CNR, the DISAFA Department (University of Turin) and the Occupational Medicine Department of the University of Catania started some tests to verify the vibration levels transmitted to an operator working with backed engine devices. Two machines have been examined: a blower and a spraying machine. Two operative conditions have been considered during all the tests: idling and full load. Three operators have been involved and each test has been repeated three times. The spraying machine has been tested both with the empty tank and with 10 litres of water, to simulate the load to be caused by the presence of liquid inside the tank. In this work the comfort condition of ISO 2631-1 standard was considered, using the frequency weighting Wc curve with the weighting factor 0.8 for $\mathrm{X}$ axis (back-ventral direction) and the Wd curve for $\mathrm{Y}$ and $\mathrm{Z}$ axis (shoulder - shoulder and buttocks - head) with weighting factors 0.5 and 0.4 (respectively for $\mathrm{Y}$ and $\mathrm{Z}$ axis). Data were examined using IBM SPSS Statistics 20 software package. The statis-
\end{abstract}

Correspondence: Roberto Deboli, Italian National Research Council, Institute for Agricultural and Earthmoving Machines (IMAMOTER), Strada delle Cacce 73, 10135 Torino, Italy.

Tel. +39.011 .3977710 - Fax: +39.011 .3489218 .

E-mail: r.deboli@imamoter.cnr.it

Key words: back vibration, back-pack power machines, blower, spraying machine.

(C) Copyright R. Deboli et al., 2013

Licensee PAGEPress, Italy

Journal of Agricultural Engineering 2013; XLIV(s2):e146

doi:10.4081/jae.2013.s2.e146

This article is distributed under the terms of the Creative Commons Attribution Noncommercial License (by-nc 3.0) which permits any noncommercial use, distribution, and reproduction in any medium, provided the original author(s) and source are credited. tical analysis underlined that the running condition is the main factor to condition the vibration levels transmitted to the operator's back, while the ballast and the operators are influent when the running conditions are distinguished. Concerning medical investigation, lower back and shoulders are the main critical part of the body interested by vibration transmitted to each operator.

\section{Introduction}

To correctly evaluate the exposure to the vibration transmitted to the workers, it is necessary to consider each body's point interested by the vibratory stimulus produced by machines. When an operator uses a portable machine equipped with an internal combustion engine (grass or leaves trimmer, blower, spraying machines or pole pruner) there are many points of the human body in contact with the vibrating tool: hands (sometimes only one), back (in function of the back pack shape more contact points may exist), shoulders (propped belts are surely contact points for vibration transmission, but also the back pack may be in contact with the shoulders).

A study carried out in 2010 on a sample of 103 green maintenance workers which used blowers (during all the four seasons, both to collect leaves and to sweep avenues and park paths) reported that the $83 \%$ of the interviewers manifested troubles using these machines, especially on shoulders and back (53\%), less to hands (20\%) and arms (15\%) (Piana et al., 2010).

Many studies report about whole body and hand-arm vibration (WBV and $\mathrm{HAV}$ ) diseases for operators using these types of forestry and agricultural machines or others, for example: Haack, 1956; Bovenzi and Betta, 1994; Bovenzi, 1998; Sörenson et al., 1997, Lines et al., 1995; Luo et al., 2000, just to cite some works, but many others exist.

On the other hand it is difficult to find studies concerning vibration transmitted to the operators' back that had evaluated the clinical/biological effects during the occupational exposure. Many epidemiological and experimental studies on hand-arm transmitted vibration have shown an high incidence and prevalence of vascular and neurological disorders (Su et al., 2012; Heaver et al., 2011), but there are no studies that have measured the hemodynamic and neurologic changes of physiological functioning in workers exposed to back vibration. A work has been done to examine the myoelectric activity of back muscles submitted to random vibration to predict muscle forces (Bluthner et al., 2001), but specific studies related to portable machines are not well known.

This fact can also be due to a lack of standards concerning this factor of risk. At the moment neither the IS0 5349-1:2001 standard gives information how to measure vibration at the operator's shoulders. For back measurements some information may be drawn from the ISO 26311:1997 standard, if the comfort condition of a sit person is considered.

If the internal combustion engine is a part of the machine, $\mathrm{C}$ stan- 
dard type exist to obtain vibration levels, as the EN ISO 22867:2012, which considers chainsaws, brush cutters, blowers and pole pruner. Nevertheless, the models of these machines without an integrated engine, but as back pack power unit, have $\mathrm{C}$ standards on vibration measurements quite incomplete.

A short notice can be found in the ISO 11680-2:2011 where the EN ISO 22867 is cited to measure the vibration transmitted to the hands by the handle with the accelerator.

Nothing is written for the vibration transmitted to the shoulders, while for the back vibration measurements, the standard refers to the IS0 2631-1. This is the standard for the whole body vibration measurement, which only mentions the danger of the vibration transmitted to the operator's shoulders by the back pack power machines, but a standard for such types of measures is not actually available.

For these reasons, in a context of shortage of data, the CNRImamoter, DISAFA and the Occupational Medicine Departments started some tests to analyze the vibration level transmitted to the back of operators using back pack power machines. Aim of the work was also to highlight differences in vibration data obtained from different operators, different machine equipments and different racing cycles.

\section{Material and methods}

\section{Tested machines}

Two machines have been tested: a blower and a portable sprayer. Their technical characteristics are written in Tables 1 and 2.

Table 1. Technical characteristics of the blower.

\begin{tabular}{lcc} 
Machine & & Blower \\
Year of production & $\mathrm{mm}$ & 2006 \\
Width & $\mathrm{mm}$ & 469 \\
\hline Length & $\mathrm{mm}$ & 328 \\
Height & $\mathrm{mm}$ & 483 \\
\hline Blow tube length & $\mathrm{m} / \mathrm{s}$ & 1520 \\
Output air speed & $\mathrm{m} 3 / \mathrm{min}$ & 125 \\
\hline Output air volume & $\mathrm{kg}$ & 20 \\
Mass & $\mathrm{rpm}$ & 10.7 \\
\hline Max rpm & $\mathrm{rpm}$ & 7070 \\
Min rpm & $\mathrm{kW}$ & 2500 \\
\hline Power & & 2.21
\end{tabular}

Table 2. Technical characteristics of the sprayer.

\begin{tabular}{lcc} 
Machine & & Sprayer \\
Year of production & & 2006 \\
Width & $\mathrm{mm}$ & 500 \\
\hline Length & $\mathrm{mm}$ & 370 \\
Height & $\mathrm{mm}$ & 740 \\
\hline Mass & $\mathrm{kg}$ & 11.4 \\
Max rpm & $\mathrm{rpm}$ & 6080 \\
\hline Min rpm & $\mathrm{rpm}$ & 2290 \\
Power & $\mathrm{kW}$ & 3.5 \\
\hline
\end{tabular}

\section{Measurement chain}

Test instruments were a vibration device Larson Davis (HVM100 model, specific for the whole body measures) coupled to a triaxial accelerometer (ICP ${ }^{\circledR}$, Integrate Current Preamplifier, PCB manufacturer, $356 \mathrm{~B} 41$ model, $10 \mathrm{~g}$ mass and with a sensitivity of $100 \mathrm{mV} / \mathrm{g}$ ), for the contemporary acquisition of vibration along the three axes ( $\mathrm{x}, \mathrm{y}$ and $\mathrm{z}$ ). The HVM100 output was connected to a computer to record the data. The frequency analysis was therefore made using the LabVIEW Signal Express software. Because the accelerometer could be tiresome for the operator's back, it was put inside a rubber shell, normally used for the whole body measures and true to the ISO 10326-1: 1992 requests (Figure 1 and 2).

To correctly evaluate the vibration transmitted to the back, the ISO 2631-1 concerning the seat back vibration was considered (4.2 paragraph). For these measures, the cited ISO uses weighing curves as well as weighting factors recommended for vibration evaluation with respect to health, comfort, perception and motion sickness: in this work the factors concerning the back vibration transmission have been treated (Table 3 ).

Only the $\mathrm{X}$ axis (back-ventral direction) with the frequency weighting $\mathrm{W}_{\mathrm{c}}$ curve and the weighting factor 0.8 must be considered for the health condition evaluation (in this case, no concern for the $\mathrm{Y}$ and $\mathrm{Z}$ axis). For the comfort judgment, indeed, the $\mathrm{W}_{\mathrm{d}}$ curve for $\mathrm{Y}$ and $\mathrm{Z}$ axis (shoulder - shoulder and buttocks - head) must be used: in this case the weighting factors are $0.8,0.5$ and 0.4 (respectively for $\mathrm{X}, \mathrm{Y}$ and $\mathrm{Z}$ axis).

In this work the comfort condition was considered.

\section{Operative conditions}

The two typical working conditions for both the machines were test-

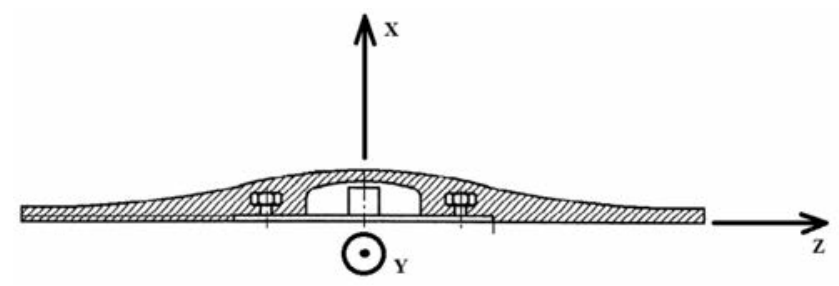

Figure 1. The semi rigid mounting disk with axes orientation

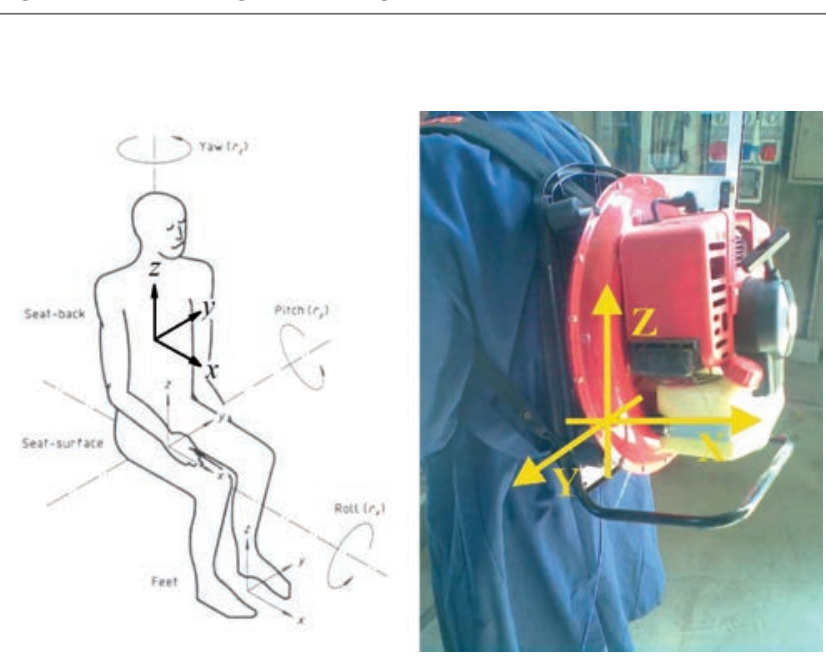

Figure 2. The whole body orientation axes for vibration measurements and application to the portable back pack blower 
ed, idle and racing. Three operators used the machines and each test was repeated three times. Each operator adjusted the machine propped belts to correctly balance the weight and to adapt the padded backpack to his back. The blower was tested in the racing condition only with one operator. For the atomizer, more test were conducted: with the empty tank, with 5 or 10 litres of water, to simulate the load when the machine is used in the true operation. The software IBM Statistic SPSS 20 software package was used to perform statistical analysis of differences.

\section{Medical investigations}

The sensorineural evaluation was performed by the combination of aesthesiometric tests: two-point discrimination (TPD) ability and depth sense perception (DSP). The tests were carried out at on quadratus lumborum muscle in right area at the beginning of the test (basal conditions) and at the end of the test.

The evaluation of the aesthesiometric thresholds, TPD and DSP, are considered reliable screening test to discover a neurological damage in the initial stage (Bovenzi et al., 1997), even if the DSP had lower sensitivity (Coughlin et al., 2001).

For the evaluation of TPD and DSP, it was used the Renfrew aesthesiometer (1969) modified by Carlson et al. (1979), already used in a previous study (Valentino et al., 2001) and here adapted for this specific anatomic area: the combination of aesthesiometric tests was used to evaluate the acute stimuli produced by the vibrations and for clinicalepidemiological evaluations in exposed workers.

In evaluating sensorineural, the survey also included the use of a questionnaire with questions designed to establish the possible occurrence in the back of subjective complaints such as: pain and paresthesias. The responses were graded according to the following scale: none, mild, moderate, persistent.

The hemodynamic analysis was conducted through an indirect assessment of the blood flow with measurement of the superficial skin temperature (SST) (Valentino et al., 2001-a). The measurement of the SST is derived from the assumption that this depends on the blood flow of cutaneous vessels.

Thermometric measurements were made on on quadratus lumborum muscle in right area, at the beginning of the test (baseline) and at the end of the test, until the return to baseline values.

For the SST measure was used a thermocouple thermometer (E 8105 Cole Parmer Instruments, USA) with a detection accuracy of $0.5^{\circ} \mathrm{C}$.

\section{Results}

For each machine, $\mathrm{x}, \mathrm{y}, \mathrm{z}$ and sum squares acceleration values are analysed and then differences among the different operative conditions are discussed. From the medical point of view, SST, TPD and DSP values obtained from each operator in the different operative conditions are reported.

\section{Blower}

Sum square values range between 0.451 to $1.082 \mathrm{~m} / \mathrm{s}^{2}$. Racing values are higher than idle ones, except for the operator B (Table 4).

Because of the few number of tests and the non normality of the distribution, the Kruskal-Wallis non parametric test $(\mathrm{p}=0.05)$ was used to evaluate vibration values uniformity among the operators along the three axis. Moreover, the analysis concerned a comparison among operators at the idle cycle and another for the operator A (idle and race cycles). In both comparisons, only the vertical $\mathrm{Z}$ axis is less affected by the operators or operative conditions.

\section{Comparison among operators: idle cycle analysis}

It does not exist uniformity in the acceleration values along the three axis among the three operators at the idling condition but, as it is confirmed by the Duncan test and it is also possible to see in Table 4, the difference is made by operator $B$ : in fact, a consequent analysis without this operator demonstrated that there are not significant differences between the other two operators ( $\mathrm{A}$ and $\mathrm{C}$ ) along the $\mathrm{X}$ axis. Differences remain along $\mathrm{Y}$ and $\mathrm{Z}$ axis (with lower acceleration values than $\mathrm{X}$ axis, but with higher spread).

\section{Comparison between idle and racing cycles}

For this analysis only one operator was involved. Highly statistical differences exist comparing the two different operative conditions: in some cases along the $\mathrm{X}$ and $\mathrm{Y}$ axis the racing acceleration values double the idle ones (Table 4).

\section{Atomizer}

Table 5 shows that acceleration values for the atomizer are lower than the blower, independently from the examined axes and, as the blower, higher values are along the $\mathrm{X}$ axis, which is the most influencing the sum square.

Data (Table 6) are normally distributed but the Levene's test found the variables $\mathrm{Y}$ and $\mathrm{Z}$ heteroscedastic (with different variance): for this reason the Kruskal-Wallis non parametric test $(\mathrm{p}=0.05)$ was preferred to the ANOVA. In this first analysis along the $\mathrm{X}$ axis acceleration values were different in function of the operator and of the ballast presence (not for the rpm): the subsequent Dunnet test found that there were not differences between the 5 or $10 \mathrm{~kg}$ ballast.

Table 3. Frequency-weighting curves and weighting factors (source: ISO 2631-1).

\begin{tabular}{lcccc} 
Axis & \multicolumn{2}{c}{ Health } & \multicolumn{2}{c}{ Comfort } \\
& $\begin{array}{c}\text { Frequency } \\
\text { weighting curve }\end{array}$ & $\begin{array}{c}\text { Weighting } \\
\text { factor (k) }\end{array}$ & $\begin{array}{c}\text { Frequency } \\
\text { weighting curve }\end{array}$ & $\begin{array}{c}\text { Weighting } \\
\text { factor (k) }\end{array}$ \\
$\mathrm{X}$ & $\mathrm{W}_{\mathrm{c}}$ & 0.8 & $\mathrm{~W}_{\mathrm{c}}$ & 0.8 \\
$\mathrm{Y}$ & - & - & $\mathrm{W}_{\mathrm{d}}$ & 0.5 \\
\hline
\end{tabular}

Table 4. Acceleration values obtained on the operators' back (X, Y, Z axis and sum square) when using the blower.

\begin{tabular}{lccccc} 
Operator & Engine status & $\begin{array}{c}\mathrm{X} \text { axis } \\
\left(\mathrm{m} / \mathrm{s}^{2}\right)\end{array}$ & $\begin{array}{c}\mathrm{Y} \text { axis } \\
\left(\mathrm{m} / \mathrm{s}^{2}\right)\end{array}$ & $\begin{array}{c}\mathrm{Z} \text { axis } \\
\left(\mathrm{m} / \mathrm{s}^{2}\right)\end{array}$ & $\begin{array}{c}\text { Sum square } \\
\left(\mathrm{m} / \mathrm{s}^{2}\right)\end{array}$ \\
\hline A & Racing & 0,691 & 0,596 & 0,314 & 0,965 \\
A & Racing & 0,620 & 0,537 & 0,286 & 0,868 \\
\hline A & Racing & 0,681 & 0,548 & 0,308 & 0,927 \\
A & Idle & 0,394 & 0,248 & 0,224 & 0,517 \\
\hline A & Idle & 0,383 & 0,307 & 0,239 & 0,546 \\
A & Idle & 0,310 & 0,244 & 0,219 & 0,451 \\
\hline B & Idle & 0,728 & 0,601 & 0,347 & 1,006 \\
B & Idle & 0,682 & 0,533 & 0,316 & 0,922 \\
\hline B & Idle & 0,796 & 0,631 & 0,372 & 1,082 \\
C & Idle & 0,399 & 0,381 & 0,274 & 0,616 \\
\hline C & Idle & 0,345 & 0,343 & 0,261 & 0,552 \\
C & Idle & 0,477 & 0,425 & 0,293 & 0,702 \\
\hline
\end{tabular}


Idle average acceleration values are always higher than the corresponding race averages along all the axis and for the sum square (Figure 3), both in the unballast and ballast states.

The high number of tests with different operative conditions along the three axes (operator, rpm, unballast, ballast) condition the registered acceleration values: for this reason, different statistical analysis were performed, to enhance likeness or differences in function of the machine state (rpm), the operator presence and the ballast.

During the idle cycle, the operator is the factor conditioning the acceleration values along the $\mathrm{X}$ axis, apart from the ballast (Table 7).

Along the $Y$ axis, values differences exist only when the ballast is present and the factor conditioning is the operator.

$\mathrm{Z}$ axis values are always different among the subsets.

Sum square values are always conditioned by the operators, as the $\mathrm{X}$ axis values (which are the most influencing the sum square).

During the racing cycle operators do not influence acceleration values along all the three axis (as well as the sum square): there are differences only along the $\mathrm{Y}$ axis in the unballast condition, Table 8 . The ballast factor, instead, influences the acceleration values along the three axis (and, as a consequence, the sum square).

During the idling cycle, when the ballast is present, the operator always influences the acceleration values along the three axis; in the unballast conditions, instead, the operator presence influences the $\mathrm{X}$ axis, more affecting the back. In this case the values along this axis are undoubtedly higher than other values of $Y$ and $Z$ axis (Table 6): for this reason the sum square values are more influenced by the $\mathrm{X}$ axis. On the other hand the operator does not influence acceleration values in the racing cycle: in this case is the ballast which lets the results to vary (Table 8).

\section{Medical investigations}

The results collected in the medical tests are summarized in Table 9 and 10 .

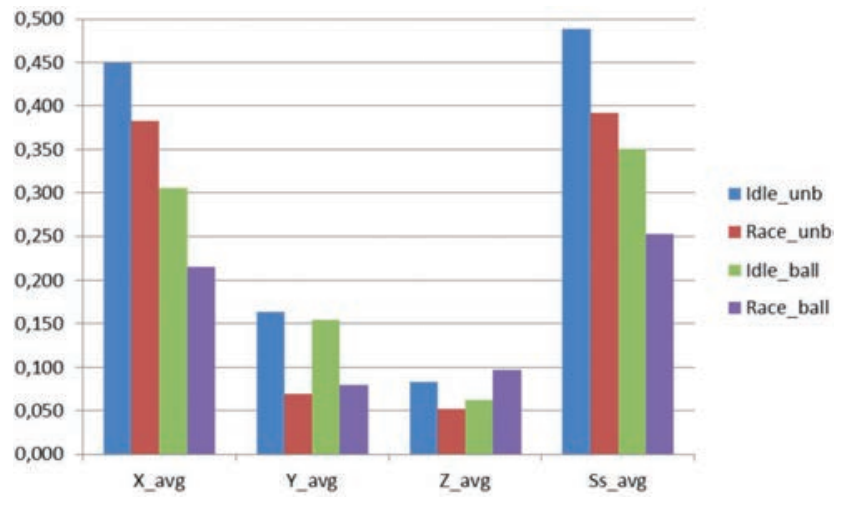

Figure 3. Averages of acceleration values along the $\mathrm{X}, \mathrm{Y}$ and $\mathrm{Z}$ axis and sum square in idle and race states, unballast and ballast conditions.

Table 5. Descriptive statistic of atomizer acceleration values.

\begin{tabular}{lcccc} 
& $\mathbf{X}$ & $\mathbf{Y}$ & $\mathbf{Z}$ & Sum_square \\
Min & 0.107 & 0.041 & 0.030 & 0.138 \\
Max & 0.547 & 0.178 & 0.542 & 0.572 \\
\hline Average & 0.303 & 0.113 & 0.088 & 0.339 \\
Dev.std & 0.120 & 0.044 & 0.029 & 0.114 \\
\hline
\end{tabular}

Analysis of results showed that values of SST, TPD and DSP were always altered after the tests compared to baseline values, both with blower and spraying machines. In particular, the SST was significantly reduced during the idle cycle. On the other hand, TPD and DSP values increased, more during the idling cycle than the racing. Data obtained

Table 6. Acceleration values obtained on the operators' back when using the atomizer.

\begin{tabular}{|c|c|c|c|c|c|c|}
\hline Operator & Cycle & $\mathrm{X}$ & $\begin{array}{c}\mathrm{Y} \\
\text { RMS*k }\left(\mathrm{m} / \mathrm{s}^{2}\right)\end{array}$ & $\mathrm{Z}$ & $\begin{array}{l}\text { Sum square } \\
\left(\mathrm{m} / \mathrm{s}^{2}\right)\end{array}$ & Note \\
\hline A & idle & 0,632 & 0,170 & 0,060 & 0,657 & - \\
\hline A & idle & 0,618 & 0,165 & 0,061 & 0,643 & - \\
\hline A & idle & 0,617 & 0,166 & 0,062 & 0,642 & - \\
\hline A & racing & 0,457 & 0,083 & 0,062 & 0,468 & - \\
\hline A & racing & 0,427 & 0,084 & 0,049 & 0,438 & - \\
\hline A & racing & 0,358 & 0,080 & 0,047 & 0,370 & - \\
\hline $\mathrm{C}$ & idle & 0,309 & 0,160 & 0,102 & 0,362 & - \\
\hline $\mathrm{C}$ & idle & 0,326 & 0,171 & 0,097 & 0,381 & - \\
\hline $\mathrm{C}$ & idle & 0,347 & 0,151 & 0,080 & 0,387 & - \\
\hline $\mathrm{C}$ & racing & 0,363 & 0,067 & 0,051 & 0,373 & - \\
\hline $\mathrm{C}$ & racing & 0,391 & 0,071 & 0,047 & 0,400 & - \\
\hline $\mathrm{C}$ & racing & 0,381 & 0,073 & 0,045 & 0,390 & - \\
\hline B & idle & 0,383 & 0,165 & 0,107 & 0,431 & - \\
\hline B & idle & 0,362 & 0,166 & 0,100 & 0,411 & - \\
\hline B & idle & 0,391 & 0,178 & 0,092 & 0,439 & - \\
\hline B & racing & 0,374 & 0,057 & 0,059 & 0,382 & - \\
\hline B & racing & 0,343 & 0,057 & 0,057 & 0,352 & - \\
\hline B & racing & 0,347 & 0,055 & 0,052 & 0,355 & - \\
\hline B & idle & 0,247 & 0,117 & 0,101 & 0,292 & ballast $5 \mathrm{~kg}$ \\
\hline B & idle & 0,298 & 0,156 & 0,098 & 0,350 & ballast $5 \mathrm{~kg}$ \\
\hline B & idle & 0,306 & 0,162 & 0,098 & 0,359 & ballast $5 \mathrm{~kg}$ \\
\hline B & racing & 0,143 & 0,074 & 0,069 & 0,175 & ballast $5 \mathrm{~kg}$ \\
\hline B & racing & 0,107 & 0,071 & 0,051 & 0,138 & ballast $5 \mathrm{~kg}$ \\
\hline B & racing & 0,121 & 0,075 & 0,046 & 0,149 & ballast $5 \mathrm{~kg}$ \\
\hline B & idle & 0,348 & 0,162 & 0,042 & 0,386 & ballast $10 \mathrm{~kg}$ \\
\hline B & idle & 0,299 & 0,151 & 0,042 & 0,338 & ballast $10 \mathrm{~kg}$ \\
\hline B & idle & 0,322 & 0,164 & 0,056 & 0,366 & ballast $10 \mathrm{~kg}$ \\
\hline B & racing & 0,314 & 0,085 & 0,131 & 0,351 & ballast $10 \mathrm{~kg}$ \\
\hline B & racing & 0,343 & 0,085 & 0,129 & 0,376 & ballast $10 \mathrm{~kg}$ \\
\hline B & racing & 0,333 & 0,081 & 0,133 & 0,367 & ballast $10 \mathrm{~kg}$ \\
\hline A & idle & 0,376 & 0,153 & 0,041 & 0,408 & ballast $10 \mathrm{~kg}$ \\
\hline A & idle & 0,392 & 0,137 & 0,032 & 0,416 & ballast $10 \mathrm{~kg}$ \\
\hline A & idle & 0,382 & 0,139 & 0,030 & 0,408 & ballast $10 \mathrm{~kg}$ \\
\hline A & racing & 0,236 & 0,079 & 0,103 & 0,269 & ballast $10 \mathrm{~kg}$ \\
\hline A & racing & 0,267 & 0,084 & 0,100 & 0,297 & ballast $10 \mathrm{~kg}$ \\
\hline A & racing & 0,281 & 0,077 & 0,095 & 0,306 & ballast $10 \mathrm{~kg}$ \\
\hline $\mathrm{C}$ & idle & 0,237 & 0,172 & 0,072 & 0,301 & ballast $10 \mathrm{~kg}$ \\
\hline $\mathrm{C}$ & idle & 0,217 & 0,171 & 0,065 & 0,283 & ballast $10 \mathrm{~kg}$ \\
\hline $\mathrm{C}$ & idle & 0,239 & 0,170 & 0,068 & 0,301 & ballast $10 \mathrm{~kg}$ \\
\hline $\mathrm{C}$ & racing & 0,158 & 0,099 & 0,082 & 0,204 & ballast $10 \mathrm{~kg}$ \\
\hline $\mathrm{C}$ & racing & 0,145 & 0,078 & 0,084 & 0,184 & ballast $10 \mathrm{~kg}$ \\
\hline $\mathrm{C}$ & racing & 0,138 & 0,073 & 0,138 & 0,209 & ballast $10 \mathrm{~kg}$ \\
\hline
\end{tabular}


in the 3 different ballast conditions (empty tank, $5 \mathrm{l}$ and $10 \mathrm{l}$ water) with the spraying machine didn't show significant differences.

\section{Conclusions}

Differences are highlighted about vibration values transmitted to the operators' back.

Table 7. Difference analysis obtained with operator and ballast variable conditioning along the three axis and the sum square in the idle cycle $(p<0.05$. No: there are significantly statistical differences. Yes: the sample may be considered homogeneous).

\begin{tabular}{|c|c|c|c|c|c|}
\hline & Variable & $X$ & $\mathrm{Y}$ & $\mathrm{Z}$ & $\begin{array}{l}\text { Sum } \\
\text { square }\end{array}$ \\
\hline $\begin{array}{l}\text { Variable } \\
\text { conditioning: } \\
\text { operator }\end{array}$ & $\begin{array}{c}\text { With or without ballast } \\
\text { With ballast } \\
\text { Without ballast }\end{array}$ & $\begin{array}{l}\text { No } \\
\text { No } \\
\text { No }\end{array}$ & $\begin{array}{l}\text { Yes } \\
\text { No } \\
\text { Yes }\end{array}$ & $\begin{array}{l}\text { No } \\
\text { No } \\
\text { No }\end{array}$ & $\begin{array}{l}\text { No } \\
\text { No } \\
\text { No }\end{array}$ \\
\hline $\begin{array}{l}\text { Variable } \\
\text { conditioning: } \\
\text { ballast }\end{array}$ & $\begin{array}{l}\text { With or without ballast } \\
\text { With ballast }\end{array}$ & $\begin{array}{l}\text { No } \\
\text { Yes }\end{array}$ & $\begin{array}{l}\text { Yes } \\
\text { Yes }\end{array}$ & $\begin{array}{l}\text { No } \\
\text { No }\end{array}$ & $\begin{array}{l}\text { No } \\
\text { Yes }\end{array}$ \\
\hline
\end{tabular}

Table 8. Difference analysis obtained with operator and ballast variable conditioning along the three axis and the sum square in the racing cycle $(\mathbf{p}<\mathbf{0 . 0 5}$. No: there are significantly statistical differences. Yes: the samples may be considered homogeneous).

Variable $\quad$ X $\quad$ Y $\quad$ Z Sum

\begin{tabular}{lccccc} 
Conditioning & Operator with or without ballast & Yes & Yes & Yes & Yes \\
variable: & Operator with ballast & Yes & Yes & Yes & Yes \\
operator & Operator without ballast & Yes & No & Yes & Yes \\
$\begin{array}{l}\text { Conditioning } \\
\text { variable: }\end{array}$ & With or without ballast & No & No & No & No \\
ballast & With ballast & No & No & No & No \\
\hline
\end{tabular}

In both the machines, $\mathrm{X}$ axis has always higher values: for the blower around 0.5 and $0.65 \mathrm{~m} / \mathrm{s}^{2}$ respectively in idling and racing cycle, for the atomizer around 0.37 and $0.28 \mathrm{~m} / \mathrm{s}^{2}$.

The blower has higher values along all the three axis than sprayer, both in the idling and racing cycles: moreover acceleration values in the race cycle are double than in the idle.

Concerning the sprayer, the operator influences nearly always the acceleration data, especially along the $\mathrm{X}$ axis, at lower rpm values. In the racing cycle, instead, accelerations are operator independent (with or without work experience), but they are influenced by the ballast.

Aesthesiometric thresholds increased after the tests in idle conditions, as well as the skin temperature was significantly reduced. These results could be explained by observing the amplitude of acceleration transmitted from tools to operators, which in fact were greater during the tests at low engine rpm.

Despite the small size of the sample studied, which does not allow generalized conclusions, we believe that the use of instruments backed induces changes in the sensitivity of the skin surface and of cutaneous temperature. Therefore, it is necessary to deepen study the biological effects produced by the use of these tools, increasing the sample and using screening instruments that can give information also on the musculoskeletal structures of the back of occupationally exposed workers.

\section{References}

Bluthner R., Seidel H., Hinz B. 2001. Examination of the myoelectric activity of back muscles during random vibration. Methodical approach and first results. Clinical Biomechanics. 16(1): S25-S30.

Bovenzi M., Betta A. 1994. Low-back disorders in agricultural tractor drivers exposed to whole-body vibration and postural stress. Appl. Ergon. 25(4): 231-241.

Bovenzi M., Apostoli P., Alessandro G., Vanoni 0. 1997. Changes over a workshift in aesthesiometric and vibrotactile perception thresholds of workers exposed to intermittent hand transmitted vibration from impact wrenches. Occup. Environ. Med. 54: 577-587.

Table 9. Mean and standard deviation of SST, TPD and DSP values obtained from each operator when using the blower.

\begin{tabular}{lcccc} 
& Baseline & Idling cycle & Baseline & \\
SST $\left({ }^{\circ} \mathrm{C}\right)$ & $31.2 \pm 0.8$ & $26.1 \pm 0.7$ & $31.5 \pm 0.8$ & $28.6 \pm 0.9$ \\
TPD mm & $7,9 \pm 0,7$ & $17,9 \pm 2,7$ & $7,8 \pm 0,9$ & $15,7 \pm 2,9$ \\
\hline DSP mm & $14,7 \pm 2,5$ & $24,1 \pm 4,2$ & $14,3 \pm 3,3$ & $19,8 \pm 3,6$ \\
\hline
\end{tabular}

Table 10. Mean and standard deviation of SST, TPD and DSP values obtained from each operator using the spraying machine in 3 different ballast condition (empty tank, $5 \mathrm{~kg}$ and $10 \mathrm{~kg}$ ).

\begin{tabular}{lcccc} 
& Baseline & Idling cycle & Baseline & Racing cycle \\
SST $\left({ }^{\circ} \mathrm{C}\right)$ - - mpty tank & $31.4 \pm 0.8$ & $26.5 \pm 0.6$ & $31.7 \pm 0.7$ & $28.5 \pm 0.9$ \\
TPD mm -empty tank & $7,5 \pm 0,4$ & $17,7 \pm 2,3$ & $12,3 \pm 2,3$ & $15,3 \pm 2,3$ \\
\hline DSP mm -empty tank & $14,5 \pm 2,1$ & $24,3 \pm 4,7$ & $14,4 \pm 3,7$ & $20,1 \pm 3,3$ \\
SST $\left({ }^{\circ} \mathrm{C}\right) 5 \mathrm{~kg}$ & $32.7 \pm 0.9$ & $26.9 \pm 1.1$ & $32.9 \pm 0.9$ & $30.6 \pm 1.1$ \\
\hline TPD mm $5 \mathrm{~kg}$ & $7,7 \pm 0,7$ & $17,6 \pm 2,1$ & $7,8 \pm 1,0$ & $14,9 \pm 2,6$ \\
DSP mm $5 \mathrm{~kg}$ & $15,1 \pm 2,9$ & $25,4 \pm 4,9$ & $14,6 \pm 3,1$ & $21,0 \pm 3,5$ \\
\hline SST $\left({ }^{\circ} \mathrm{C}\right) 10 \mathrm{~kg}$ & $32.3 \pm 0.5$ & $28.7 \pm 0.5$ & $32.8 \pm 0.8$ & $31.3 \pm 0.6$ \\
TPD mm $10 \mathrm{~kg}$ & $7,7 \pm 0,7$ & $18,3 \pm 2,1$ & $7,8 \pm 1,0$ & $13,4 \pm 3,2$ \\
\hline DSP mm $10 \mathrm{~kg}$ & $14,7 \pm 2,4$ & $26,2 \pm 4,5$ & $15,1 \pm 3,8$ & $22,4 \pm 4,1$ \\
\hline
\end{tabular}


Bovenzi M. 1998. Exposure-response relationship in the hand-arm vibration syndrome: an overview of current epidemiology research. Int. Arch. Occup. Environ. Health. 71: 509-519.

Carlson W.S., Samueloff S., Taylor W., Wasserman D.E. 1979. Instrumentation for measurement of sensory loss in fingertps. J Occup Med. 21: 260-264.

Coughlin P.A., Bonser R., Turton E.P., Kent P.J., Kester R.C. 2001. A comparison between two methods of aesthesiometric assessment in patients with hand-arm vibration syndrome. Occup. Med. 51: 272277.

European Commission Enterprise And Industry. 2010. Guide to application of the Machinery Directive 2006/42/EC. Ian Fraser Editor.

International standards: ISO, 2001. Mechanical vibration Measurement and evaluation of human exposure to hand-transmitted vibration. ISO 5349-1. International Organization for Standardization Publ., Geneva, Switzerland.

International standards: ISO 1997. Mechanical vibration and shock Evaluation of human exposure to whole-body vibration. ISO 26311. International Organization for Standardization Publ., Geneva, Switzerland.

European standards: EN 1996. Mechanical vibration - Declaration and verification of vibration emission values. EN 12096. Brusseles, Belgium.

European standards: EN 2012. Forestry and gardening machinery Vibration test code for portable hand held machines with internal combustion engine - Vibration at the handles. EN ISO 22867. Brusseles, Belgium.

International standards: ISO 2011. Machinery for forestry - Safety requirements and testing for pole-mounted powered pruners - ISO 11680-2. International Organization for Standardization Publ., Geneva, Switzerland.

International standards: ISO 1992. Mechanical vibration - Laboratory method for evaluating vehicle seat vibration. ISO 10326-1. International Organization for Standardization Publ., Geneva,
Switzerland.

Haack M. 1956. Human tolerance to vibrations in farm machines. Agr. Eng. 37(4): 253-257.

Heaver C., Goonetilleke K.S., Ferguson H., Shiralkar S. 2011. Hand-arm vibration syndrome: a common occupational hazard in industrialized countries. J. Hand Surg. Eur. 36(5): 354-63.

Lines J.A., Stiles M., Whyte R.T. 1995. Whole Body Vibration During Tractor Driving. Journal of Low Frequency Noise and Vibration. 14(2): 87-104.

Luo J., Sakakibara H., Zhu SK. 2000. Effects of vibration magnitude and repetitive exposure on finger blood flow in healthy subjects. Int. Arch. Occup. Environ. Health. 73: 281-284.

Renfrew S. 1969. Fingertip sensation: a routine neurological test. Lancet. 1(7591): 396-7.

Sörensson A., Burström L. 1997. Transmission of vibration energy to different parts of the human hand-arm system. Int. Arch. Occup. Environ. Health. 70: 199-204.

Su A.T., Darus A., Bulgiba A., Maeda S., Miyashita K. 2012. The clinical features of hand-arm vibration syndrome in a warm environmenta review of the literature. J Occup Health. 54(5): 349-60.

Piana E.A., Marchesini A., Deboli R., Preti C. 2010. Rischio da esposizione a vibrazioni per l'uso di soffiatori a zaino: valutazione dell'esposizione a vibrazioni trasmesse al corpo intero e alla spalla. Atti del $37^{\circ}$ Convegno Nazionale AIA. Siracusa, Italia.

Valentino M., Rapisarda V., Solina G., Cenerelli F. 2001. Esposizione a vibrazioni del sistema mano braccio: indagine di screening sulle modificazioni neurologiche. Atti del $64^{\circ}$ Congresso Nazionale della Società Italiana di Medicina del Lavoro e Igiene Industriale, Roma, Italia. G. Ital. Med. Lav. 23: 266.

Valentino M., Rapisarda V., Paone N., Di Giulio G., Rossi G.L. 2001-a. Esposizione a vibrazioni del sistema mano-braccio. Atti del Congresso Nazionale della Società Italiana degli Igienisti Industriali, Napoli, Italia. 357-360. 